\title{
Correction to: Responses to relaxed and reverse selection in strains artificially selected for duration of death-feigning behavior in the red flour beetle, Tribolium castaneum
}

\author{
Kentarou Matsumura ${ }^{1} \cdot$ Takahisa Miyatake $^{1}$ (D)
}

Published online: 31 December 2018

(c) The Author(s) 2018

\section{Correction to: Journal of Ethology (2018) 36:161-168 https://doi.org/10.1007/s10164-018-0548-x}

The article Responses to relaxed and reverse selection in strains artificially selected for duration of death-feigning behavior in the red flour beetle, Tribolium castaneum, written by Kentarou Matsumura and Takahisa Miyatake was originally published electronically on the publisher's internet portal (currently SpringerLink) on 4 April, 2018 without open access. With the author(s)' decision to opt for Open Choice the copyright of the article changed on 31 December, 2018 to () The Author(s) 2018 and the article is forthwith distributed under the terms of the Creative Commons Attribution 4.0 International License (http://creativecommons .org/licenses/by/4.0/), which permits use, duplication, adaptation, distribution and reproduction in any medium or format, as long as you give appropriate credit to the original author(s) and the source, provide a link to the Creative Commons license and indicate if changes were made.

The original article has been corrected.

Open Access This article is distributed under the terms of the Creative Commons Attribution 4.0 International License (http://creativeco mmons.org/licenses/by/4.0/), which permits unrestricted use, distribution, and reproduction in any medium, provided you give appropriate credit to the original author(s) and the source, provide a link to the Creative Commons license, and indicate if changes were made.
The original article can be found online at https://doi.org/10.1007/ s10164-018-0548-x.

Takahisa Miyatake

miyatake@okayama-u.ac.jp

1 Graduate School of Environmental and Life Science, Okayama University, Okayama City, Japan 